Richard D. Oram

\title{
Living on the Level: Horizontally Planned Lodgings in Fifteenth- and early Sixteenth-Century Scotland
}

\begin{abstract}
Horizontally integrated public spaces and private accommodation in enfilade (i.e. entered in sequence one from another) were presented by Charles McKean as the successor in Scottish elite planning from around the 1520 s to the vertically disposed provision of earlier towers. ${ }^{1}$ Architectural innovation there certainly was in what is often labelled Scotland's early Renaissance period, and the efflorescence of buildings of this basic plan within houses of the Scottish nobility from the late 1530s onwards suggests an enthusiastic embracing of the new prescription for elite living that it offered. This paper argues, however, that, rather than being a new departure of the 1500 s, such buildings were present by the later fifteenth century, already forming the principal apartments of major courtyard 'palace' complexes in both royal and lordly contexts; and as an architectural expression of power they have too often been literally overshadowed by towers.
\end{abstract}

A tradition of vertically-disposed high-status space dominated but did not monopolise Scottish castle design from the thirteenth to sixteenth centuries. At the residences of royalty and nobility alike, the stacking of hall and chamber(s) in turriform was a common but not universal practice. Epitomised in Scotland by the Douglas Tower at Tantallon of the later 1350s, David's Tower at Edinburgh or Threave in Galloway in the late 1360s and 1370s, and the great towers of Dundonald and Doune in the 1360s to early $1400 \mathrm{~s}^{2}$ it was a style favoured also across contemporary northern Europe. Much ink has been spilled on asserting that such towers were Scotland's contribution to European elite architecture, ${ }^{3}$ but the manifest importance of tower-building as an expression of royal and lordly power within the European mainstream renders such arguments hollow. The Europe-wide significance and long chronology of towerbuilding as a projection of secular authority is illustrated by the examples of Vincennes commenced for King John II of France in 1361 and completed by his son, Charles V, in $1369,{ }^{4}$ the episcopal castle of Gjorslev in Denmark of c. $1400,{ }^{5}$ the 'Yellow Tower of Gwent' at Raglan in Wales of the 1430s, ${ }^{6}$ or Lord Hastings' tower at Ashby de la Zouch in England of 1474-83. ${ }^{7}$

The persistent over-emphasis on verticality in discussion of later medieval Scottish elite architecture, consequent largely on Stewart Cruden's adherence to MacGibbon and Ross's form-based chronological scheme of the late 1880s, has been challenged for a quarter of a century. ${ }^{8}$ Cruden's dogmatic assertion that while some 'tower-houses' were expanded in the fifteenth century and served as 'the nucleus of a more expansive establishment ranged round a courtyard,' this was expeditious and 'not indicative of a real change in architectural thought', ${ }^{9}$ entirely missed the point that many such expansions were wholly consequent on exactly such changes in both architectural thought and the social performance of lordship in new settings. These changes, viewed generally as signalling the dawn of something conventionally labelled the 'early Renaissance', are often presented as radical departures from previous 'medieval' traditions, but the cleavage implicit in those labels has been seen as a down-playing of continuities and a stress on disjunctions. It is a false dichotomy which a generation of research on late medieval Scottish elite culture and society has largely eliminated from historical discourse but which persists in architectural discussion. 
James I's palace at Linlithgow signalled something new in the sequence of spaces that foreshadowed the horizontal circulation within the quadrangular plan that had evolved there by the early $1500 \mathrm{~s} .{ }^{10}$ Linlithgow's later fifteenth-century form had high-status accommodation stacked in towers flanking the hall to north and south, while suites of apartments for the king and queen were still later formed in the west and north quarters. (Figure 1) That layout has been largely attributed to James IV and James V's remodelling of Linlithgow and, with little evidence for James II and James III's contributions surviving in an interpretable state there or elsewhere, there is a hiatus in evidence for trends in Scottish royal residential planning between 1437 and 1488. When the evidence trail resumes under James IV, it is apparent that the thinking signalled by his great-grandfather's showpiece palace had become established in Scotland's architectural repertoire. That shift by no means indicated an abandonment of turriform arrangements for royal lodgings - as the surviving James V tower at Holyroodhouse demonstrates - but it presaged greater emphasis on horizontality through the sixteenth century.

Although the horizontal disposition of the principal chambers of royal and lordly residences in both Scotland and northern Europe has tended to be portrayed as a 'Renaissance' phenomenon, a de-emphasis on verticality in the sixteenth century was hardly innovative. In France before 1400, after Charles V's monumental donjon at Vincennes, horizontally arranged logis gained currency as a favoured format for the principal residential components of royal and magnate castles. ${ }^{11}$ Before 1460 , the form was dispersed across the kingdom, exemplified by Charles VII's logis royal completed in the 1440s or 1450s within its own enclosure outside the earlier château at Loches, the duke of Alençon's logis at Fougères, or the recently excavated and analysed later fourteenth- and fifteenth-century logis constructed for the lords of Dinan inside their older château at Guildo in Brittany. ${ }^{12}$ In England, horizontality coupled with an emphasis on balance in show façades was an established feature of royal architecture even earlier. The exemplar here was probably the upper ward frontage of Edward III's apartments at Windsor, completed c. $1365,{ }^{13}$ which provided inspiration for his son John of Gaunt's work at Kenilworth and subsequent late fourteenth- and fifteenth-century residential blocks within castles throughout England. $^{14}$

\section{Bothwell Castle}

The emphasis on the tower in the historiography of the Scottish castle, exemplified by massive monoliths like Borthwick Castle, and the apparent uniqueness of Linlithgow, however, has obscured the presence of buildings constructed with the emphasis on the horizontal axis in pre-sixteenth-century Scotland. A problem of survival compounds this situation, for much that remains is fragmentary, has undergone later alteration, or is known only from documentary references, but substantial horizontally organised late medieval buildings are recognisable. At Bothwell Castle, for example, scholarly attention is concentrated on its thirteenth-century development and the late fourteenthcentury replacement of its cylindrical donjon by a square tower at the opposite end of the complex, ${ }^{15}$ ignoring the two-storey range that extends along most of the castle's south front. (Figure 2) Architectural discussion of Bothwell makes minimal reference to this range, which was remodelled probably for the $4^{\text {th }}$ and $5^{\text {th }}$ Earls of Douglas before $c .1435$, or to other accommodation that the $3^{\text {rd }}$ earl, whose main residence this was from the $1350 \mathrm{~s}$, provided for his household in this quarter of the complex. ${ }^{16}$ 
From the evidence of the fenestration and raggles of partition walls, it was a twostorey building oriented east-west with a courtyard frontage some $40 \mathrm{~m}$ in length. (Figure 3) Although the upper level was modernised in the sixteenth century, the earlier internal divisions were maintained. How those divisions were linked internally, e.g. in a sequence of chambers of progressively increasing privacy, is irrecoverable from the surviving fabric. The south-facing windows of the courtyard level rooms are large and of high quality, indicating that these were residential spaces. Placed opposite the principal gate of the castle's inner close, this two-storey range probably presented a fine façade to the north similar to contemporary French logis. Its integration into the principal public spaces of the late medieval arrangements is emphasised by how its upper rooms were linked to the adjoining fifteenth-century hall-block through the first-floor chapel in the easternmost half of the south range, chapel and chambers being entered via an external stair to a grand doorway at their junction-point. This arrangement echoes that of Bishop Traill at St Andrews Castle, where his chambers in the Fore Tower communicated with the hall in the east range through the first-floor chapel in the south-east range. Given the French influence strongly evident in the architectural detailing of this period at Bothwell, it is tempting to see the horizontal sequence of chamber, chapel and hall as inspired by the logis visited by the Douglases in Anjou, Maine and Touraine, but insufficient structure survives to enable that link to be made with confidence.

Innovative as Bothwell's south range lodging appears, it maintained links to the Scottish turriform tradition. Balanced to the west by the remaining half of the original donjon and its adjoining latrine and 'prison' tower and on the east by the round south-east and square north-east towers, it embodied modernity bracketed by the symbols of ancient lordship. ${ }^{17}$ The principal accommodation of the Douglases in the late 1300 s probably had been in the north-east tower, while the cylindrical southeast tower contained a stack of chambers for important members of the household. In the early 1400s, however, they had built more spacious accommodation disposed like the logis at Chinon along the south curtain to capitalise on views of the Clyde below. This insertion of new integrated public and private space into the carapace of the old was a hallmark of the Douglases, being employed also at Balvenie in Moray, where James Douglas, earl of Avondale (younger brother of Archibald, $4^{\text {th }}$ earl of Douglas), or James's youngest son John, lord Balvenie, constructed a new suite of principal chambers in a two-storey block along the north-west side of the thirteenth-century enclosure. Although almost as heavily ruined as Bothwell's south range and overshadowed by the splendid mid-sixteenth-century Atholl Lodging at the south-east of the courtyard, ${ }^{18}$ enough survives to reveal that this was a suite disposed in enfilade, comprising of a hall (connected to the kitchen range in the south-west quarter), outer or chamber of dais and inner chamber, all at first-floor level over a range of vaulted cellars. Thirteenth-century Balvenie lacked a Bothwell-style donjon and the evidence of antiquity preserved by the Douglases was embodied instead in the curtain wall.

\section{The King's Old Building, Stirling Castle}

Fragmentary though these examples are, they reveal significant investment in horizontally planned accommodation amongst the Scottish nobility before 1450; Linlithgow is simply a royal expression of an established design trend. In them we see the genesis of structures regarded as signalling a decisive transition from medieval to Renaissance thinking in Scottish high-status residential design, amongst which that at the highest part of Stirling's castle rock, known since at least the 1680s as 'The King's Old Building', is regarded as being of central importance. ${ }^{19}$ In contrast to other 
elements of Stirling's inner close - the Chapel Royal, Great Hall and James V's Palace - in its existing form The King's Old Building is an anticlimactic presence at what should be the most prestigious part of the complex. Indeed, its much-altered state both internally and externally for long led to its neglect in discussions of Stirling's architectural development. This neglect is typified by MacGibbon and Ross's comment that 'the west side of the courtyard, where the oldest buildings of the Castle originally stood, is now occupied with comparatively modern and uninteresting buildings'. ${ }^{20}$ That dismissal was replaced by the 1930s by John Richardson's cautious suggestion that, despite significant alterations and a substantial post-fire rebuild in the 1800s, The King's Old Building had 'probably served as the Royal lodging before the Palace was built'. ${ }^{21}$ Although he ventured no chronology, his assignment of a role to it as royal accommodation before James $\mathrm{V}$ commenced construction of his palace in the late 1530s pushed its origins back at least to James IV's reign. Survey by RCAHMS in the 1950s saw further re-dating, this time pushing it into the middle decades of the sixteenth century after the building of the palace. ${ }^{22}$ Consolidation work in the 1970s and 1980s, however, revealed much of the structure to be considerably older and it was suggested that it was the 'King's House' for which the master mason Walter Merlioun received a belated contract in June 1496; the Treasurer's Accounts record that work on it was, in fact, nearing completion around that time. ${ }^{23}$ This discovery enabled The King's Old Building to be understood for the first time as an exemplar of planning for Scottish royal semi-public and private space at the close of fifteenth century.

What that structural re-analysis revealed is that while the middle and northern sections probably represent Merlioun's work for James IV, the southern compartment includes walls on an earlier alignment. ${ }^{24}$ As completed in the 1490 s, this composite building was a long, roughly rectangular block aligned north-south along the cliffedge, with a shorter east-west range returning at right-angles at its north end. The main entrance and access to the upper floor was in the southern of two towers that now project from its courtyard façade (the northern dates from the nineteenth-century post-fire refurbishment). The late fifteenth-century stair-tower rises at the junction of the southern compartment and the main section of the 1490s building. (Figure 4) The courtyard level of the 1490s block was remodelled in the eighteenth and nineteenth centuries, but sufficient remains to show that it had comprised of five vaulted chambers, each with separate doorway and large window in the east wall. There were two further similarly designed vaulted chambers beneath the east-west range at the north end. No explicit record survives to indicate the function of these rooms but they were finished to a standard that suggests, like at Bothwell, a more elevated role than cellarage. Given the status of The King's Old Building as the principal residential and semi-public suite of the late fifteenth-century castle, these rooms were perhaps 'lodgings' for gentlemen of the king's household, to be added to the brief list of examples of such provision in fifteenth- to seventeenth-century Scottish castles offered by Stewart Cruden. ${ }^{25}$

The surviving structural evidence for the late fifteenth-century lay-out of the upper level of the structure is more exiguous, but it is believed to have been a single storey albeit around double the height of its vaulted undercroft. A 1719 Board of Ordnance plan made before its partitioning and heightening to form officers' accommodation shows a large chamber occupying around two-thirds of the main block north of the entrance tower, with a second chamber forming the remaining third. ${ }^{26}$ From this information and surviving evidence of an unusually large fireplace in the southern compartment, the first-floor arrangements are interpreted from south 
to north as a kitchen serving a hall (probably with a screens passage at its southern end where it was also entered from the main stair), with chamber beyond. ${ }^{27}$ The main north-south block continued past that chamber, with space for a second, much smaller chamber. At its extreme north-west there is a latrine turret which vented over the cliffedge. It is suggested that the east-west block contained more intimate rooms, or closets, reached from the chamber behind the hall. A second, smaller spiral stair was inserted in the angle between the chamber and the closets, presumably to give private access to both, but this does not appear to have been part of the original design. It is unlikely that there was no other access than the south-east stair turret, but in general terms it seems that the upper storey housed a suite of rooms of increasing privacy and intimacy arranged en suite and progressing south to north.

\section{Castle Campbell}

Parallels have been drawn between The King's Old Building and the south range of Castle Campbell near Dollar. ${ }^{28}$ (Figure 5) Dated to the later 1490s or early 1500s, its builder was Archibald Campbell, $2^{\text {nd }}$ earl of Argyll and Chancellor of Scotland, who was personally familiar with James IV's lodging at nearby Stirling. What Archibald built at Castle Campbell, his principal Lowland seat, replaced a commodious suite of stacked chambers in the fifteenth-century great tower that dominates the complex and perhaps also a fifteenth-century hall on either the east or south side of the courtyard. As at Stirling, the principal rooms were at first-floor level, but similar to the older arrangement at Balvenie were carried on five tunnel-vaulted cellars and a pend that linked the courtyard with gardens on the headland south of the castle rather than on individual residential rooms as at Bothwell or Stirling. The difference potentially indicates that fewer gentlemen requiring private accommodation attended Argyll at his Lowland residence. Access to the upper levels was contained in two stair turrets, whose superstructures change form from square to octagonal, giving the strongest visual reference to The King's Old Building. The public stair is at the west end and the more private one rises in the re-entrant between the south and east ranges.

Between these turrets was a two-storey lean-to containing a basement service passage linking the cellars with the kitchen on the first-floor and a covered passage at upper level joining the western service end of the range with the private chambers at the east end.The first floor of the main block proper is heavily ruined but enough survives to show a sequence of four spaces of unequal size. These run from a western 'low' end containing the kitchen, through the semi-public space of the hall into the increasing privacy of a chamber of dais and finally an inner room which was probably Archibald's bed-chamber. (Figure 6) Entered from both the dais end of the hall and from the private stair/service passage, the chamber of dais offered both private dining and reception facilities; unlike the hall it was furnished with a latrine closet.The inner chamber, too, was accessible from the private stair as well as from the chamber of dais. It also has latrine provision in a mural closet. There were two levels of chambers above the earl's accommodation at the west end of the range and the east end appears to have been carried up in a similar fashion - visually a mini-Linlithgow - while the central component over the hall and chamber of dais contained a loft for storage. ${ }^{29}$

\section{Caerlaverock Castle}

While Castle Campbell's south range is structurally similar to James IV's lodgings at Stirling, a close parallel to Bothwell is the west range of Caerlaverock Castle. With its façade partly obscured by remnants of the state apartments of the seventeenthcentury south range and marred by later masonry buttressing to prevent the outward 
collapse of the wall through subsidence, few visitors give it much attention. On close inspection, however, it is found to be a work of high quality and sophisticated planning. It was perhaps the principal public space and private residential component of the castle before the seventeenth-century remodelling that provided the interior of the courtyard with its striking eastern façade. For most modern observers, it is the eastern range, a somewhat forbidding Renaissance lodging constructed for Robert Maxwell $1^{\text {st }}$ Earl of Nithsdale in the late 1630s, which grabs the attention within the tight central triangle of the complex. As a structure, this has deservedly attracted considerable architectural and art historical analysis. ${ }^{30}$ By way of contrast, there has been little discussion of the west range: MacGibbon and Ross devoted just three sentences to it and offered a general 'probably the first half of the sixteenth century' date for it and associated work elsewhere in the castle; ${ }^{31}$ Watson in 1923 was barely more fulsome in his account, according it a mere four sentences but stressing the quality of its design and likely importance of the rooms it contained. ${ }^{32} \mathrm{He}$ differed from MacGibbon and Ross in his dating of the range, placing it closer to 1500 but still within the sixteenth century. By the 1950s, O’Neil had pushed that dating into the second half of the fifteenth century and identified it as a building 'which may have owed something to the ideas of the Renaissance'. ${ }^{33}$ It is a somewhat grudging recognition of the range's internal design and external appearance, and this tone may account for the almost complete omission of Caerlaverock from discussion of early Renaissance secular architecture in Scotland. ${ }^{34}$

Nithsdale's seventeenth-century reconfiguration of the east and south ranges of the castle obliterated the later medieval arrangements there. The surviving remains, however, indicate that the principal apartments of fifteenth-century Caerlaverock occupied the rear extension of the twin-towered gatehouse at the northern apex of the triangle. The first floor of this ensemble was a great chamber, later subdivided by a partition wall. A now reduced late fifteenth-century doorway at its east end and a similar but now blocked opening into a lobby at its west end linked this chamber and its associated rooms within the first-floor level of the cylindrical gate-towers to whatever structures flanked the courtyard to east and west. The principal public access was via an external timber stair to the western doorway and it was opposite that door and probably reached from the head of the same stair that the $4^{\text {th }}$ Lord Maxwell provided his house with a new suite of chambers. (Figure 7)

As first built, the west range was a two-storey block, unvaulted, with four selfcontained ground floor rooms (for ease of reference hereafter numbered 1 to 4 from north to south), two or three rooms in enfilade at first floor, and a separate first-floor room at its south end (for ease of reference hereafter numbered 1.1 to 4.1). Room 4 has a modern opening into the originally windowless basement of the cylindrical thirteenth-century south-west angle tower, but there is no evidence for any earlier doorway here. The east wall of Room 4 is reduced to foundations but continued on the same alignment as the rest of the block. A door-jamb at the southern end of the remaining east walls suggests that Room 4 was accessed at some period through a doorway in a re-entrant angle between the west range and a return that extended east along the south curtain, but the junction of the west range with an earlier south range has been destroyed by the $1^{\text {st }}$ earl's building programme. All that can be suggested is that the southernmost compartment and Room 4.1 above it were physically integral to the west range but perhaps also linked to a precursor of the seventeenth-century south range. As with the examples already discussed, there was no internal communication between ground and first floors; room 1.1 certainly was entered directly through a doorway at its north-east corner. That doorway was originally reached from the 
external stair to the first-floor hall in the gatehouse, but this was superseded in the early sixteenth-century by an enclosed newel stair that served both the west range and the upper storeys of the gatehouse. Although this external access doorway has been remodelled in both the sixteenth and seventeenth centuries, the position of the fireplace in room 1 to respect the placing of the north-east doorway in 1.1 indicates that this was the original access point. Room 2.1 was entered from 1.1 through a doorway at the east end of their party wall and it is possible that 3.1 was entered from 2.1 in similar fashion through what seems to have been a timber partition wall. There was no internal communication between 3.1 and 4.1, which suggests that the southernmost room was also reached via an external stair.

Although sadly battered and suffering from subsidence that has caused the east façade to lean outwards, this west range was finished to a very high quality throughout. Rooms 1-3, for whose length the east wall is intact, each have independent entrances from the courtyard and single large windows, fitted up for shutters in their lower half and grooved and checked for glass in the upper. All three have large fireplaces of good quality in their cross walls; there is no surviving evidence of a fireplace in room 4 . In room 1, the fireplace is set into the north gable wall of the range. The party wall between rooms 1 and 2 is broad enough to take the flue of the fireplace in room 2, but that between rooms 2 and 3 was much thinner and not designed to be load-bearing. In room 3 , therefore, the fireplace is at the south end in the party wall between it and room 4 . The fireplaces in rooms 1 and 2 are positioned towards the west end of the cross walls to keep their flues clear of doorways in the first floor, while the fireplace in room 3 is towards the east with that in room 4.1 towards the west to allow separate flues in their party wall. Like at Stirling, the chambers on the upper floor are higher, with double-height windows that were originally divided by stone transoms and mullions. Room 1.1 has two windows facing the courtyard with a fireplace between them. Now a single space - and perhaps remodelled as such in the seventeenth century - the presence of two fireplaces suggests that the next compartment to the south was divided into two rooms, 2.1 and 3.1, of unequal size. The first space, 2.1, has a fireplace at the north end of its east side with a window to its south separated by a narrow masonry column from the next window. That column probably marks the location of the late fifteenth-century transverse partition. Room 3.1 has been a fine chamber of similar scale to 1.1, with two windows flanking a fireplace. Although its eastern wall has been almost entirely demolished, the courtyard façade of 4.1 is of similar length to 2.1, probably indicating that it had a single window overlooking the courtyard, but its fireplace was in its party wall with 3.1 rather than in the east wall. This arrangement would have given external symmetry to the block. In their original form, none of these rooms had west-facing windows until a large opening was slapped through the west curtain in the seventeenth century, when 2.1 and 3.1 were perhaps broken into a single space.

What was the function of the west range? In his 1952 guide, O'Neil suggested that it was built as guest accommodation. ${ }^{35}$ Certainly, with the possible exception of the apparently fire-less room 4, the whole block comprised habitable space of high architectural quality. The ground floor rooms provided individual privacy with a degree of comfort and might indeed have been for privileged guests, but they have closer parallels in the accommodation at contemporary English magnate residences for gentlemen in attendance on the castles' lords. As the leader of his district and head of an extensive kin-network, Lord Maxwell had a substantial following requiring accommodation. Rooms 1.1 to 3.1 - representing around 75 per cent of the available floor-space at the upper level - however, formed a single suite of chambers arranged 
in enfilade and with a single point of entry from the north. This is very generous space provision for a guest and is much closer in disposition but not in scale to the guard, presence and bed-chamber sequence provided in the late 1530s at Stirling. Apart from the inconvenience of the lack of a private stair between the courtyard and the inner chambers, this suite otherwise offers the progressively more private space present at Balvenie, Stirling's King's Old Building and Castle Campbell, and probably constituted a modern replacement of the first-floor chambers in the gatehouse.

\section{Conclusion}

The examples discussed here have illustrated the presence from at least the first decades of the fifteenth century in Scottish magnate architecture of a tradition of horizontally-planned accommodation that shares affinities with the French logis and English lodgings traditions of the late fourteenth and fifteenth centuries. Built on two storeys with either separately entered residential chambers or cellars on the ground floor, the upper level contained a suite of at least three rooms entered enfilade and of progressively increasing privacy the deeper one penetrated from the main access point. In most cases, the outermost room was the hall - often with a direct service link to the kitchen - followed by inner and outer chambers, but at Bothwell and Caerlaverock there seem to have been suites of smaller chambers without the grand space of a hall; that was provided elsewhere in the complex at both examples. Identification of this tradition somewhat diminishes the notion of new departure and 'Renaissance' innovation that has been suggested for The King's Old Building, indicating rather that it represented a link in a sequence that extends back around a century and which looks forward to the palace complexes of the mid-sixteenth century. More importantly, perhaps, it sinks another nail into the coffin of that historiographical tradition which almost revelled in a vision of Scottish isolation from supposedly 'mainstream' architectural developments. Rather than retreating in impoverished cultural conservatism into their cramped, bunker-like towers to lick their collective wounds in the aftermath of the destructive Wars of Independence, Scotland's great lords were active participants in a European tradition of spacious, gracious, horizontal living.

\section{Captions:}

Figure 1: Linlithgow Palace, east range showing the hall at centre flanked by the two residential towers. (C) R. Oram)

Figure 2: Bothwell Castle, south façade of lodgings from south-east. (@ R. Oram) Figure 3: Bothwell Castle, courtyard looking east with hall block at left, chapel and south-east tower centre, and site of lodgings at right. (C R. Oram)

Figure 4: Stirling Castle, The King's Old Building, showing original entrance and stair tower at centre left. (@ R. Oram)

Figure 5: Castle Campbell, exterior façade of south range. (@ R. Oram)

Figure 6: Castle Campbell, south range from the great tower, with private stair on left, basement service passage at bottom, dais end of hall and chamber of dais at centre.

(C) R. Oram)

Figure 7: Caerlaverock Castle, the west range [R Oram].

\footnotetext{
${ }^{1}$ C. McKean, The Scottish Chateau: The Country House of Renaissance Scotland, Stroud, 2001, Chapter 5 .

${ }^{2}$ See discussion of this tradition in R. Oram, 'The Greater House in Late Medieval Scotland: Courtyards and Towers c.1300-c.1400', in M. Airs and P. S. Barnwell (eds), The Medieval Great
} 
House, Donington, 2011, pp. 43-60; R. D. Oram, 'Dundonald, Doune and the Development of Tower and Hall in Late Medieval Scottish Lordly Residences', Château Gaillard, 25, 2012, pp. 269-79.

${ }^{3}$ See, for example, S. Cruden, The Scottish Castle, Edinburgh, 1981, p. 104; W. D. Simpson, The Ancient Stones of Scotland, London, 1965, p. 212.

${ }^{4}$ For its internal layout under Charles V, see http://en.chateau-vincennes.fr/rubrique.php?ID=1003554

${ }^{5}$ V. Etting, The Royal Castles of Denmark During the $14^{\text {th }}$ Century, Copenhagen, 2010, pp. 72-4.

${ }^{6}$ J. R. Kenyon, 'The Yellow Tower of Gwent: Raglan Castle, Monmouthshire, Wales', in R. D. Oram (ed), A House Such as Thieves Might Knock At, Donington, 2015, pp. 63-77.

${ }^{7}$ R. A. Brown, English Castles, Woodbridge, 2004, pp. 97-98.

${ }^{8}$ The first serious challenge occurred nearly ninety years ago in W. M. Mackenzie, The Medieval Castle in Scotland, London, 1927, a book whose measured but much-neglected critique of the MacGibbon and Ross scheme - and of the problems of false etymologies such as 'keep' - should form the starting point for any modern assessment. The most recent assault started with Chris Tabraham's 'The Scottish medieval towerhouse as lordly residence in the light of recent excavation', Proceedings of the Society of Antiquaries of Scotland, Vol. 118,1988, pp. 267-76, but the principal revision remains McKean, Scottish Chateau, especially Chapters 1-3.

${ }^{9}$ Cruden, Scottish Castle, pp. 128-129.

${ }^{10}$ I. Campbell, 'Linlithgow's "Princely Palace” and its Influence in Europe', Architectural Heritage, Vol. 5, 1994, pp. 1-20.

${ }^{11}$ See discussion in J. Mesqui, 'Les ensembles palatiaux et princiers en France au xiv ${ }^{\mathrm{e}}$ et $\mathrm{xv} \mathrm{v}^{\mathrm{e}}$ siècles', in A. Renoux (ed), Palais Royaux et Princiers au Moyen Âge, Le Mans, 1997, pp. 51-70.

${ }^{12}$ C. Amiot, 'Nouvelles observations sur le logis de Fougères en Bretagne', Mémoires de la Société d'histoire et d'archéologie de Bretagne, Vol. 78, 2000, pp. 401-434; L. Beuchet, 'Un example de résidence seigneuriale Bretonne au XV $\mathrm{X}^{\mathrm{e}}$ siècle, le Logis du Château du Guildo (Côtes-D'Armor)', Château Gaillard, 20, 2002, pp. 41-50.

${ }^{13}$ A. Emery, Greater Medieval Houses of England and Wales, 1300-1500: Southern England, Cambridge, 2006, pp. 196-7.

${ }^{14}$ See A. Amery, 'Introductory Reflections', in M. Airs and P.S. Barnwell (eds), Medieval Great House, Donington, 2011, p.18.

${ }^{15}$ Most recently in A. Rutherford and J. Malcolm, "“That stalwart toure": Bothwell Castle in the Thirteenth and Early Fourteenth Century', in A. Dakin, M. Glendinning and A. Mackechnie (eds), Scotland's Castle Culture, Edinburgh, 2011, pp. 189-198.

${ }^{16}$ W. D. Simpson, 'The Architectural History of Bothwell Castle', PSAS, Vol. 59, 1924-5, p. 178; W. D. Simpson, Bothwell Castle, Edinburgh, 1958, p. 21 for a three-sentence description of its courtyard side, but pp. 17-18 for a description of its exterior frontage. C. J. Tabraham, Scotland's Castles, London, 2005, pp. 75-6, describes fifteenth-century Bothwell as 'centred on a lofty tower house (now largely gone) and a great hall'. There is no mention of the south range.

${ }^{17}$ For discussion of Bothwell's towers in the late fourteenth century, see Rutherford and Malcolm, 'That stalwart toure'. The visual symbolism of such towers in the sixteenth century is discussed in McKean, Scottish Chateau, Chapter 5.

${ }^{18}$ McKean, Scottish Chateau, pp. 110-112.

${ }^{19}$ R. Fawcett, Stirling Castle, London, 1995, pp. 35-9.

${ }^{20}$ D. MacGibbon and T. Ross, The Castellated and Domestic Architecture of Scotland, 5 vols, Edinburgh, 1887, Vol. 1, p. 478.

${ }^{21}$ J. S. Richardson and M. E. B. Root, The Castle of Stirling, Edinburgh, 1948, p. 11.

${ }^{22}$ RCAHMS, Stirlingshire: an Inventory of the Ancient Monuments, 2 vols, Edinburgh, 1963, Vol. 1, pp. 216-8.

${ }^{23}$ Fawcett, Stirling Castle, pp. 35-6; T. Dickson and J. Balfour Paul (eds), Accounts of the Lord High Treasurer of Scotland, Vol. 1 (1473-98), Edinburgh, 1877, p.277 (payment to Walter Merlioun for his contract 'of bigging of the Kingis hous' dated 8 June 1496); pp.275-276 (payments in May 1496 for roofing materials).

${ }^{24}$ Fawcett, Stirling Castle, p. 37.

${ }^{25}$ Cruden, Scottish Castle, pp. 185-6.

${ }^{26}$ Reproduced in Richardson and Root, Castle of Stirling, plate 4; RCAHMS, Stirling, Vol. 1, pl. 59.

${ }^{27}$ Fawcett, Stirling Castle, pp. 36-7.

${ }^{28}$ R. Fawcett, Scottish Architecture from the Accession of the Stewarts to the Reformation 1371-1560, Edinburgh, 1994, pp. 267-8.

${ }^{29}$ That was its function in 1595: see N. D. Campbell, 'The Castle Campbell Inventory: An Inventory of Archibald, $7^{\text {th }}$ Earl of Argyll's Castle of Campbell (formerly called Castle Gloume), in the Shire of 
Clackmannan, taken on 21 February 1595. Transcribed from the Original Preserved in the Argyll Charter Chest', Scottish Historical Review, Vol. 10, 1913, pp. 299-305.

${ }^{30}$ G. P. H. Watson, 'The development of Caerlaverock Castle', Proceedings of the Society of Antiquaries of Scotland, Vol. 57, 1923, pp. 29-40; J. Hunwicke, 'Robert Maxwell of Caerlaverock and his fashionable windows', Transactions of the Dumfriesshire and Galloway Natural History and Antiquarian Society, Vol. 68, 1993, pp. 107-21; J. Gifford, Dumfries and Galloway, London, 1996, pp. 140-50.

${ }^{31}$ MacGibbon and Ross, Castellated and Domestic Architecture of Scotland, Vol. 1, p. 131.

${ }^{32}$ Watson, 'Development of Caerlaverock Castle', p. 38.

${ }^{33}$ B. H. St J. O’Neil, Caerlaverock Castle (HMSO, 1952), 14.

${ }^{34}$ Charles McKean was one of the few recent architectural historians to mention the building. In Scottish Chateau, pp. 94 and 165, he cautiously attributed the west range to Robert, $5^{\text {th }}$ Lord Maxwell (1513-46), but the sculptural detail suggests rather that it was his father John, $4^{\text {th }}$ Lord Maxwell, who fell at Flodden, who commissioned the work.

${ }^{35}$ O’Neil, Caerlaverock Castle, p. 7. 